\title{
Influence of environmental variables and anthropogenic perturbations on stream fish assemblages, Upper Paraná River, Central Brazil
}

\author{
Nicelly B. Araújo ${ }^{1}$ and Francisco L. Tejerina-Garro ${ }^{2}$
}

The Ouvidor River, a tributary of the Upper Paraná River, drains areas covered by cerrado vegetation in Central Brazil. We collected data for environmental variables (water temperature, dissolved oxygen, $\mathrm{pH}$, conductivity, turbidity, water velocity, luminosity, channel substrate and width) and anthropogenic perturbations (industry, reservoirs, urban areas) that may structure the fish assemblage in ten stream sites of the Ouvidor River basin. In each stream we delimited one $50 \mathrm{~m}$ long site where fish were captured by electrofishing and abiotic data were collected every two month between August 2004 and June 2005. Coinertia analysis indicated that $\mathrm{pH}$, water velocity, channel width and water temperature most strongly structured the fish assemblages. The interactions of water velocity and channel width with the fish assemblage were not directly affected by wet and dry seasons but the opposite was true for $\mathrm{pH}$ and water temperature.

O rio Ouvidor é um tributário do Alto rio Paraná, Brasil Central, que drena áreas cobertas por vegetação do tipo Cerrado. Em dez cursos d'água da bacia do referido rio foram coletados dados referentes às variáveis ambientais (temperatura de água, oxigênio dissolvido, $\mathrm{pH}$, condutividade, turbidez, velocidade da água, luminosidade, substrato do canal e largura) e perturbações antropogênicas (indústria, represas, área urbana) que poderiam estruturar as assembléias de peixes. Em cada curso d'água foi delimitada uma estação de $50 \mathrm{~m}$ de comprimento, onde bimestralmente entre agosto de 2004 e junho de 2005 os peixes foram capturados utilizando-se a pesca elétrica e coletados os dados abióticos. A análise de co-inércia indicou que o pH, a velocidade da água, a largura do canal e a temperatura da água são os fatores que mais fortemente estruturaram as assembléias de peixes. A interação da velocidade da água e a largura do canal com as assembléias de peixes não foram afetadas diretamente pelo regime hidrológico regional (chuva e estiagem), enquanto que o contrário é observado para as variáveis $\mathrm{pH}$ e temperatura da água.

Key words: Neotropical fish, Goiás State, Cerrado.

\section{Introduction}

The structural and functional characteristics of aquatic communities respond to environmental oscillations that differ in spatial and temporal scales (Matthews, 1998). Four physical habitat characteristics are widely recognized as directly important for fish species distribution and abundance in streams: water depth (Angermeier \& Karr, 1994; Penczak et al., 1994), current velocity (Mendonça et al., 2005), composition of the channel substrate (Cunico et al., 2006) and riparian vegetation cover (Ferreira \& Casatti, 2006a; Mérigoux et al., 1998; Penczak et al., 1994). Metrics representing these characteristics aid analyses of habitat modification on fish assemblages (Tejerina-Garro et al., 2005). However, fish assemblages are also influenced by other characteristics of the aquatic environment such as the historic/biogeographic conditions, water temperature, flow regime, predation, competition, and diseases (Poff et al., 1997; Jackson et al., 2001).

In the Neotropical region, interest in stream fish ecology is relatively recent (Oliveira \& Bennemann, 2005), including the influence of environmental variables on fish assemblage structure (Fialho et al., 2008). Consequently, there have been few studies concerning this subject in the upper Paraná River basin. Abes \& Agostinho (2001) reported that the variable set of channel width, depth, water and air temperature, dissolved oxygen, conductivity, $\mathrm{pH}$ and substrate influenced fish richness and assemblage composition. Penczak et al. (1994) found that $\mathrm{pH}$, conductivity, depth, channel width, and pres-

${ }^{1}$ Programa de Pós-graduação em Ecologia e Produção Sustentável, Universidade Católica de Goiás - Campus II, Avenida Engler s/n, Jardim Mariliza, 74605-010, Goiânia, Goiás, Brazil.nicellybraudes@gmail.com

${ }^{2}$ Centro de Biologia Aquática, Universidade Católica de Goiás - Campus II, Avenida Engler s/n, Jardim Mariliza, 74605-010, Goiânia, Goiás, Brazil.garro@ucg.br 
ence of macrophytes structured fish assemblages. Conductivity, water temperature, $\mathrm{pH}$, dissolved oxygen (Braga \& Andrade, 2005) and $\mathrm{pH}$, water temperature, conductivity, chemical dissolved oxygen, and turbidity (Fialho et al., 2008) were also related to differences in fish assemblage structure. However, these relationships were also affected by anthropogenic impacts related to different land uses (Penczak et al., 1994) such as domestic sewage, agriculture, ranching, and urbanization (Fialho et al., 2008). Despite their similarities in stream hydromorphology, neotropical streams are historically and geomorphologically different. Also, any environmental modification, natural or anthropogenic, can influence local fish zoogeography and modify the fish assemblage composition to some degree via local species extirpations (Gorman \& Karr, 1978; Tonn, 1990) and introductions (Lomnicky et al., 2007). The lack of knowledge about fish faunas and environmental change in neotropical regions like those of the Central Brazil are of concern to ichthyologists and ecologists because regional biodiversity is unknown and some species appear to be disappearing of some streams even before it is possible to establish their spatial distribution (Tejerina-Garro, 2008)

The aim of this article is to identify which environmental variables (water temperature, dissolved oxygen, $\mathrm{pH}$, conductivity, turbidity, water velocity, luminosity, channel substrate and width) and anthropogenic perturbations (industry, reservoirs, urban area) most structure the fish assemblages in streams sites of the Upper Paraná River, Central Brazil.

\section{Material and Methods}

Study area. The Ouvidor River basin is located in southern Goiás State, Central Brazil, and is a tributary of the Upper Paraná River, the second largest drainage basin of South America (Lowe-McConnell, 1999). The climate is semi-arid with marked wet and dry seasons, and air temperature varying between $16.9^{\circ} \mathrm{C}$ and $37.2^{\circ} \mathrm{C}$. The predominant soil in the basin is red latosol (IBGE, 2005). The sampled stream sites (Table 1) have narrow $(<8 \mathrm{~m})$ and shallow $(<1 \mathrm{~m})$ channels. Their substrate is formed predominately by sand and gravels (Buraco, Olhos d'água, Posse dos Rodrigues, Riacho streams), bedrock (Lagoa, Ouvidor and Taquara II), or mud (Taquara I). The sites were bordered by riparian vegetation typical of the cerrado biome (Ribeiro, 1998), pasture (Ouvidor, Posse dos Rodrigues, Riacho, Olhos d'água streams) or industrial areas (Taquara II and Santo Antônio). Some channels were fragmented by reservoirs (Taquara I, Buraco, Sapê streams), received domestic sewage (Santo Antônio) or drained urban areas (Lagoa).

Sampling protocols. Fish, environmental variables and anthropogenic perturbations data were collected from one site in each of nine streams and one upper reach of the Ouvidor River main channel (Fig. 1, Table 1) every two months between August 2004 and June 2005 to assess changes in the fish
Table 1. Streams sites sampled in the Ouvidor River basin and their geographic coordinates.

\begin{tabular}{lccc}
\hline Site & Code & \multicolumn{2}{c}{ Geographic coordinates } \\
& & S & W \\
\hline Taquara II & TII & $18^{\circ} 09^{\prime} 16.6^{\prime \prime}$ & $47^{\circ} 52^{\prime} 37.1^{\prime \prime}$ \\
Taquara I & TI & $18^{\circ} 09^{\prime} 32.3^{\prime \prime}$ & $47^{\circ} 51^{\prime} 08.5^{\prime}$ \\
Buraco & B & $18^{\circ} 09^{\prime} 40.2^{\prime \prime}$ & $47^{\circ} 49^{\prime} 46.1^{\prime \prime}$ \\
Santo Antônio & SA & $18^{\circ} 12^{\prime} 18.6^{\prime \prime}$ & $47^{\circ} 52^{\prime} 34.9^{\prime \prime}$ \\
Lagoa & L & $18^{\circ} 15^{\prime} 16.7^{\prime \prime}$ & $47^{\circ} 49^{\prime} 25.6^{\prime \prime}$ \\
Ouvidor & Ouv & $18^{\circ} 17^{\prime} 47.6^{\prime \prime}$ & $47^{\circ} 52^{\prime} 48.7^{\prime \prime}$ \\
Posse dos Rodrigues & PR & $18^{\circ} 18^{\prime} 09.0^{\prime \prime}$ & $47^{\circ} 52^{\prime} 49.8^{\prime \prime}$ \\
Riacho & R & $18^{\circ} 18^{\prime} 48.2^{\prime \prime}$ & $47^{\circ} 55^{\prime} 15.8^{\prime \prime}$ \\
Sapê & S & $18^{\circ} 21^{\prime} 28.2^{\prime \prime}$ & $47^{\circ} 53^{\prime} 30.0^{\prime \prime}$ \\
Olhos d'água & Od & $18^{\circ} 23^{\prime} 21.3^{\prime \prime}$ & $47^{\circ} 54^{\prime} 28.8^{\prime \prime}$ \\
\hline
\end{tabular}

assemblages associated with seasonality (Welcomme, 1979). In each stream, a $50 \mathrm{~m}$ long site was delimited based on easy access conditions, its geographic coordinates (Garmin 12) were obtained, and six transects every ten meters were marked.

Fish were sampled by electrofishing, which is efficiently for collecting small fish species (Severi et al., 1995) in lotic environments (Mazzoni et al., 2000). The electrofishing equipment was powered by a portable generator (HONDA, 1800 $\mathrm{W}, 220 \mathrm{~V}$ ) connected to a DC transformer then two electrified net rings (anode and cathode). Output voltage varied from 100 to $600 \mathrm{~V}$. Each reach was fished three times from downstream to upstream by three people following the protocol suggested by Esteves \& Lobón-Cerviá (2001). Collected fish were fixed in $10 \%$ formalin and identified to species or genus in the laboratory. Voucher specimens of each species were deposited in the Museu de Ciências e Tecnologia, Pontifícia Universidade Católica do Rio Grande do Sul, Brazil.

Channel width, substrate, water velocity and luminosity (total luminous flux incident on the channel surface) and the anthropogenic perturbations were measured at each transect. Water temperature and dissolved oxygen were measured at the first, third and sixth transects and the $\mathrm{pH}$, conductivity and turbidity were measured at the center of each reach (Table 2).

Data analysis. The data matrices consisted in presence/absence values aiming to treats dominant species equally than rare species (McCune \& Grace, 2002), qualitative variables values (channel substrate and anthropogenic perturbations), and average quantitative variables values for each reach. All data were grouped by season (wet and dry). The fish and qualitative and quantitative data matrices were submitted separately to Principal Component Analysis (PCAs). In the case of the quantitative data, the PCA was performed using the correlation method recommended when data collected was measured in different unities, whereas covariance was used for the fish and qualitative data because it was measured in the same unit (Dolédec \& Chessel, 1991). Then the results of each PCA were submitted to a co-inertia analysis (COI) separately (fish $v s$. quantitative variables; fish vs. qualitative). We used multivariate ordination of COI because it is sensitive to a small number of samples (10 sites; Dolédec \& Chessel, 1994) and aids identification of fish assemblage patterns resulting from the influence of the variables considered 


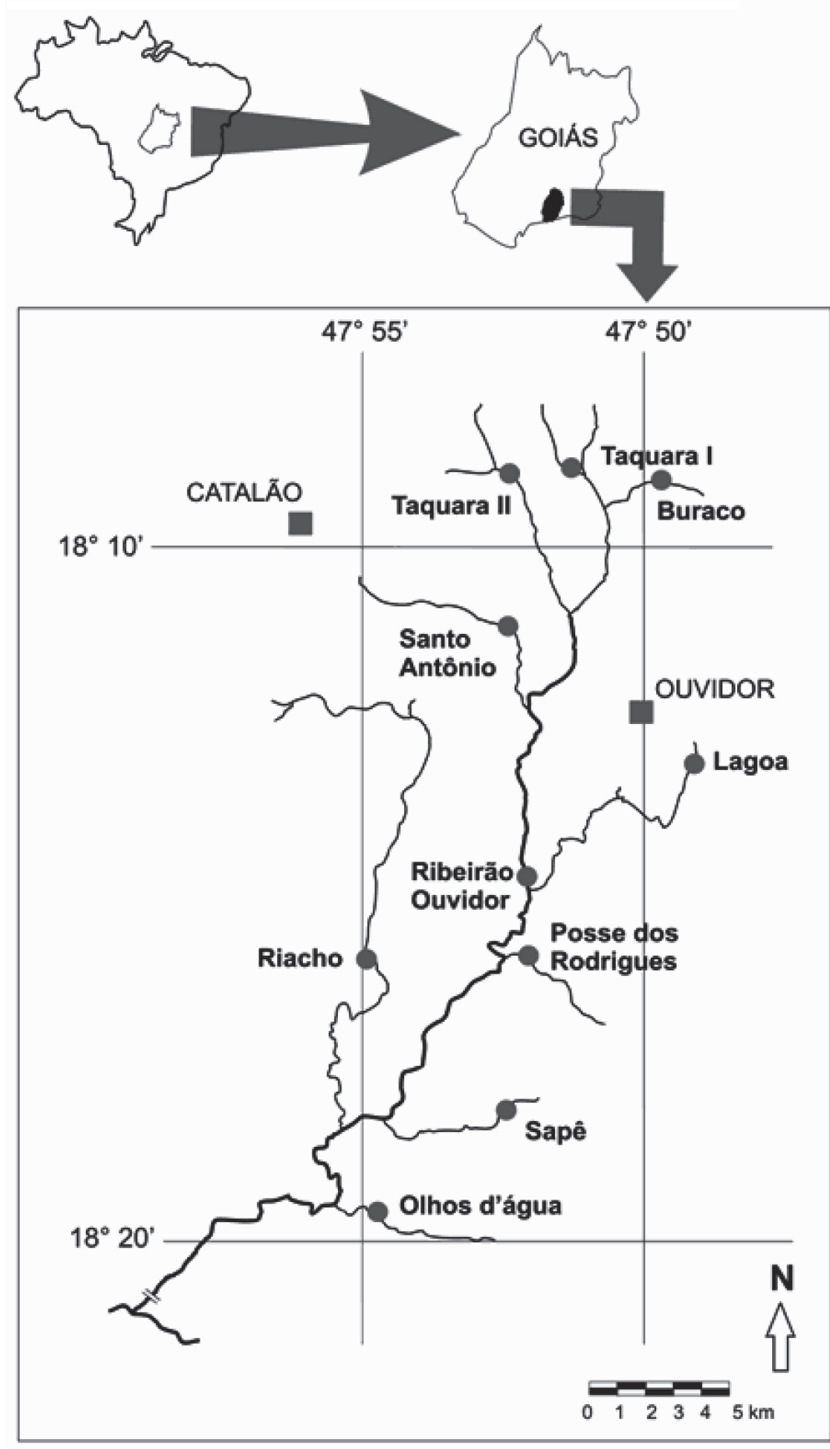

Fig. 1. Locations of the sampled sites (dots) in the streams of the Ouvidor River, Goiás State, Brazil. Squares indicate the main cities.
(McCune \& Grace, 2002). The co-structure between fish assemblages and variables resulting from the co-inertia analysis was tested using a Monte Carlo test (1000 iterations). The collinearity between quantitative variables resulting from the PCA was tested using a Pearson correlation test (Zar, 1998). All analyses were performed using ADE-4 software (Thioulouse et al., 2001).

\section{Results}

We collected 4049 specimens and 35 fish species (Table $3)$. Fish abundance was high at the Buraco site during the dry (601 specimens) and wet (641) seasons. Conversely, low abundance was observed at the Lagoa (76, dry season) and Taquara I (11, wet season) sites.

The COI analysis indicated that the co-structure between the fish matrix and the quantitative variables was significant ( $\mathrm{p}=0.000$; characin $P$. argentea and the catfish $C$. cf. iheringi, Hisonotus sp., Hypostomus sp. and H. margaritifer) but not with the qualitative variables $(\mathrm{p}=0.084$; Table 4$)$. In the first case, two axes explained $70.74 \%$ of the total inertia and the correlation (r) between the fish assemblage and the quantitative variables was significant (axis $1=0.86$; axis $2=0.90$; Table 4). On axis 1, the ordination of fish assemblages and stream reaches was related to water velocity and channel width in the dry and wet seasons (Fig. 2). The fish assemblages represented by these species were associated with reaches with the higher water velocities and wider channels observed in the Ouvidor River and Riacho stream (right sides of Figs. 2a-b; Table 5). By contrast, fish species such as the characin $H$. aff. malabaricus and the cichlid $T$. rendalli were related to stream reaches with low water velocities and narrow channel widths as observed in the Buraco and Sapê streams during dry season (Fig. 2; Table 5).

On axis 2, fish assemblages and sites were discriminated by $\mathrm{pH}$ and water temperature seasonally (Fig. 2; Table 4). In the dry season, the characins Bryconamericus sp.2, P. myersi, A. eigenmanniorum, A. piracicabae, Bryconamericus sp.1

Table 2. Qualitative and quantitative variables measured in the Ouvidor River and its tributaries.

\begin{tabular}{|c|c|c|c|c|c|}
\hline Local & Type & Variable & Code & Category & Method/Equipment \\
\hline \multirow[t]{3}{*}{ Landscape } & Qualitative & Anthropogenic perturbation & - & City & \multirow{3}{*}{ Visual } \\
\hline & & & - & Industry & \\
\hline & & & - & Reservoir & \\
\hline \multirow[t]{12}{*}{ Channel } & Qualitative & Channel substrate & - & Sand & \multirow{4}{*}{ Visual } \\
\hline & & & - & Gravel & \\
\hline & & & - & Mud & \\
\hline & & & - & Rock & \\
\hline & \multirow[t]{8}{*}{ Quantitative } & Channel width (m) & $\mathrm{CW}$ & - & Tape measure \\
\hline & & Water velocity $(\mathrm{cm} / \mathrm{s})$ & WV & - & General Oceanic 2030 Series \\
\hline & & Water temperature $\left({ }^{\circ} \mathrm{C}\right)$ & WT & - & Lutron DO-5510 \\
\hline & & Luminosity (lux) & LU & - & Polaris \\
\hline & & Dissolved oxygen (mg/L) & DO & - & Lutron DO-5510 \\
\hline & & $\mathrm{pH}$ & $\mathrm{pH}$ & - & Lutron PH-206 \\
\hline & & Conductivity $(\mu \mathrm{S} / \mathrm{cm})$ & $\mathrm{CO}$ & - & WTW315i \\
\hline & & Turbidity (UTN) & TU & - & LaMotta2020 \\
\hline
\end{tabular}


and the catfish $H$. nigricans were associated with sites, except Olhos d'água and Lagoa, where the water was acidic and the temperature low (superior side of Figs. 2a-b; Table 5). In the wet season H. margaritifer and P. nasus were associated with sites characterized by elevated water temperature and alkaline $\mathrm{pH}$ such as displayed by the streams Posse dos Rodrigues, Olhos d'água and Lagoa (Fig. 2; Table 5).

\section{Discussion}

One goal of ecosystem ecology is to establish how assemblages of organism, in this case fish, are related to environmental oscillations (Braga, 2004). Such relationships are characterized by the simultaneous influence of multiple environmental variables on assemblages (Bini, 2004). This also was the case in this study, where four variables (water velocity, channel width, water temperature and $\mathrm{pH}$ ) structured fish assemblages to the greatest degree among the variables measured.

In our study, water velocity and the channel width were little affected by seasonality as normally occurs in natural conditions (Poff et al., 1997; Tejerina-Garro \& Mérona, 2001).This situation is often related to modification of stream hydrology by reservoirs, but reservoirs did not significantly influence many of our sites and fish assemblage ordination results. Reservoirs are known to regulate water velocity and channel width downstream (Mérona et al., 2005), increase water residence time (Thomaz et al., 1997), increase downstream substrate size (Oliveira \& Lacerda, 2004), and consequently alter biotic communities (Agostinho et al., 1992). This likely only occurred in sites with low water velocities and narrow channel such as Taquara I, Buraco and Sapé, each of which were located upstream of a reservoir.

In this study the relationship of catfish $(C$. cf. iheringi, Hisonotus sp., Hypostomus sp. and H. margaritifer) and characin (P. argentea) to sites with elevated water velocities and wide channels can be explained in part by the interaction of environmental filters and the functional characteristics of these species (Poff, 1997). Some of the sites sampled had rocky substrates and pools; both of which provide habitat for algae (Esteves, 1988; Bennemann et al., 2005) and subsequently herbivorous catfish species such as Hisonotus and

Table 3. Relative abundance of fish species by site. $\mathrm{B}=$ Buraco; $\mathrm{L}=$ Lagoa; $\mathrm{Od}=$ Olhos d'água; Ouv = Ouvidor; $\mathrm{PR}=$ Posse dos Rodrigues; $\mathrm{R}=$ Riacho; $\mathrm{S}=$ Sapê; $\mathrm{SA}=$ Santo Antônio; TI = Taquara I; TII = Taquara II.

\begin{tabular}{|c|c|c|c|c|c|c|c|c|c|c|c|c|c|c|c|c|c|c|c|c|c|c|}
\hline \multirow[t]{3}{*}{ Species } & \multirow[t]{3}{*}{ Code } & \multicolumn{20}{|c|}{ Stream site } & \multirow[t]{3}{*}{ Total } \\
\hline & & \multicolumn{10}{|c|}{ Dry season } & \multicolumn{10}{|c|}{ Wet season } & \\
\hline & & $\mathrm{B}$ & $\mathrm{L}$ & $\mathrm{Od}$ & Ouv & PR & $\mathrm{R}$ & $\mathrm{S}$ & SA & TI & TII & $\mathrm{B}$ & $\mathrm{L}$ & Od & Ouv & $\mathrm{PR}$ & $\mathrm{R}$ & $\mathrm{S}$ & SA & TI & TII & \\
\hline Apareiodon ibitiensis & Apaibi & - & - & - & - & - & - & - & 0.02 & - & - & - & - & - & 0.07 & 70.1 & - & - & - & - & - & 0.19 \\
\hline Apareiodon piracicabae & Apapir & - & - & 0.02 & - & 0.17 & - & - & - & - & - & - & - & 0.05 & $5-$ & - & - & - & - & - & - & 0.24 \\
\hline Astyanax altiparanae & Astalt & - & - & - & 0.05 & 2.89 & 0.27 & 3.21 & 2.32 & 2.84 & 0.89 & - & 0.07 & - & 0.12 & 1.28 & 0.05 & 1.06 & 60.59 & 0.12 & 0.27 & 16.03 \\
\hline Astyanax cf. fasciatus & Astfas & 5.21 & 0.2 & 0.07 & 0.17 & 0.12 & 0.62 & 0.77 & 1.48 & 0.02 & 1.43 & 7.09 & 0.3 & 0.27 & 0.07 & 70.15 & 0.02 & 0.1 & 0.4 & - & 0.32 & 18.81 \\
\hline Astyanax eigenmanniorum & Asteig & 1.43 & 0.02 & 0.07 & 0.12 & 0.05 & 0.12 & - & - & - & 0.05 & - & - & - & - & - & - & - & - & - & - & 1.86 \\
\hline Bryconamericus sp.1 & Brysp1 & - & 0.05 & - & 0.15 & 0.35 & 0.32 & - & 0.1 & 0.02 & 0.2 & - & - & - & 1.38 & 0.02 & - & 0.1 & 0.05 & - & - & 2.74 \\
\hline Bryconamericus sp. 2 & Brysp2 & - & - & - & 0.1 & - & - & 0.12 & 0.15 & 0.02 & - & - & - & - & - & - & - & - & - & - & 0.02 & 0.41 \\
\hline Cetopsorhamdia cf. iheringi & Cetihe & - & 0.07 & 0.77 & 0.05 & - & 0.05 & - & 0.02 & - & - & - & 0.05 & 0.1 & - & - & - & - & - & - & - & 1.11 \\
\hline Characidium fasciatum & Chafas & 1.53 & - & - & - & - & 0.02 & - & - & 0.02 & - & 2.54 & - & - & 0.02 & - & - & - & - & - & - & 4.13 \\
\hline Characidium gomesi & Chagom & - & - & - & - & - & - & - & - & - & - & - & 0.05 & - & - & - & - & - & - & - & - & 0.05 \\
\hline Cichlasoma paranaense & Cicpar & 0.47 & - & - & 0.12 & 0.42 & 0.07 & 1.98 & 0.84 & 1.19 & 0.27 & 0.72 & - & - & 0.12 & 0.12 & 0.02 & 1.48 & 80.4 & 0.12 & 0.05 & 8.39 \\
\hline Cyphocarax modestus & Cypmod & - & 0.02 & - & - & - & - & - & - & - & - & - & - & - & - & - & - & - & - & - & - & 0.02 \\
\hline Gymnotus carapo & Gymcar & - & 0.25 & - & 0.05 & 0.1 & 0.02 & 0.05 & 0.05 & 1.53 & 0.4 & - & 0.79 & - & 0.02 & 0.07 & - & 0.05 & - & - & 0.25 & 3.63 \\
\hline Hisonotus sp. & Hissp & - & 0.02 & 0.17 & 0.02 & - & 0.02 & - & - & - & - & - & - & - & - & - & - & - & - & - & - & 0.23 \\
\hline Hoplias aff. malabaricus & Hopmal & 0.12 & - & - & - & 0.15 & - & 0.22 & 0.02 & 0.07 & - & 0.35 & - & - & - & 0.02 & - & 0.12 & - & - & 0.05 & 1.12 \\
\hline Hyphessobrycon sp. & Hyphsp & - & - & - & - & - & - & - & - & - & - & 0.25 & - & 0.07 & - & - & - & - & 0.02 & - & - & 0.34 \\
\hline Hypostomus ancistroides & Hypanc & - & - & - & 0.07 & - & - & 0.07 & - & - & - & - & - & - & - & - & - & - & - & - & - & 0.14 \\
\hline Hypostomus margaritifer & Hypmar & - & 0.17 & 0.22 & 0.35 & - & - & - & - & - & - & - & 0.07 & 0.25 & 0.07 & 70.1 & 0.15 & 0.07 & - & - & - & 1.45 \\
\hline Hypostomus nigricans & Hypnig & - & 0.1 & 0.02 & 0.07 & - & - & 0.05 & 0.07 & - & - & - & - & - & - & 0.05 & - & - & - & - & - & 0.36 \\
\hline Hypostomus regani & Hypreg & - & 0.02 & - & 0.07 & 0.05 & - & - & - & - & - & - & - & - & - & - & - & - & - & - & - & 0.14 \\
\hline Hypostomus sp. & Hypsp & - & 0.17 & - & 0.15 & ; - & 0.02 & - & - & - & - & - & - & - & - & 0.12 & - & - & - & - & - & 0.46 \\
\hline Imparfinis sp. & Impsp & - & - & - & - & - & - & - & - & - & - & 0.05 & - & - & - & - & - & - & - & - & - & 0.05 \\
\hline Laetacara $\mathrm{sp}$ & Laesp & - & - & - & - & - & - & - & 0.02 & - & 0.07 & - & - & - & 0.02 & - & 0.05 & - & 0.02 & - & 0.02 & 0.20 \\
\hline Leporinus microphthalmus & Lepmic & - & - & - & 0.02 & - & - & - & - & - & 0.1 & - & - & - & - & - & - & - & - & - & - & 0.12 \\
\hline Neoplecostomus paranensis & Neopar & - & - & - & - & - & - & - & 0.07 & - & - & - & - & - & 0.02 & 0.02 & - & 0.02 & 20.1 & - & - & 0.23 \\
\hline Parodon nasus & Parnas & - & 0.1 & 2.05 & 0.05 & - & 0.02 & 0.15 & 0.07 & - & 0.1 & - & 0.05 & 1.26 & 0.12 & 0.05 & - & 0.07 & 70.12 & - & 0.02 & 4.23 \\
\hline Phenacorhamdia sp. & Phesp & - & - & - & - & - & - & - & - & - & - & - & - & - & - & - & - & - & 0.02 & - & - & 0.02 \\
\hline Piabina argentea & Piaarg & - & 0.62 & 0.07 & 0.15 & 0.05 & 0.74 & 0.32 & 2.35 & - & 0.22 & - & 0.12 & 0.15 & 0.79 & 1.06 & 0.27 & 0.17 & 71.28 & - & 0.22 & 8.58 \\
\hline Pimelodus sp. & Pimsp & - & 0.02 & - & - & - & - & - & - & - & - & 0.02 & 0.05 & 0.17 & $7-$ & 0.02 & - & - & - & - & - & 0.28 \\
\hline Planaltina myersi & Plamye & 0.05 & - & - & - & - & - & - & - & - & - & 0.17 & - & - & - & - & - & - & - & - & - & 0.22 \\
\hline Poecilia reticulata & Poeret & 4.62 & - & - & 0.17 & 0.62 & - & 1.88 & 3.01 & 0.05 & 0.22 & 3.46 & 0.05 & - & 0.57 & 70.2 & - & 1.14 & 41.73 & 30.02 & 0.17 & 17.91 \\
\hline Rhamdia quelen & Rhaque & 0.2 & 0.02 & 0.67 & 0.4 & 0.1 & 0.05 & 0.1 & 0.15 & 0.59 & 0.07 & 0.59 & 0.02 & 0.37 & 0.15 & 0.07 & 0.02 & 0.05 & 50.05 & $5-$ & - & 3.67 \\
\hline Synbranchus marmoratus & Synmar & - & - & - & - & 0.02 & - & - & 0.02 & - & - & - & 0.02 & - & - & - & - & - & 0.02 & - & - & 0.08 \\
\hline Tilapia rendalli & Tilren & 0.32 & - & - & - & - & - & - & 0.37 & - & - & 0.02 & - & - & - & - & - & - & 0.05 & - & - & 0.76 \\
\hline Trichomycterus sp. & Trisp & 0.89 & - & 0.02 & - & - & - & - & - & - & - & 0.57 & - & - & - & - & - & - & - & - & - & 1.48 \\
\hline Total & & 14.84 & 1.88 & 4.17 & 2.35 & 5.09 & 2.37 & 8.92 & 11.16 & 6.37 & 4.03 & 15.83 & 1.65 & 2.69 & 3.58 & 3.48 & 0.59 & 4.45 & 54.87 & 70.27 & 1.41 & 100.00 \\
\hline
\end{tabular}


Table 4. Fish species, quantitative and qualitative variables contribution (\%) to axes and statistics of the co-inertia analysis. Boldface values indicate major contributions.

\begin{tabular}{|c|c|c|c|c|}
\hline \multirow[t]{3}{*}{ Description } & \multicolumn{4}{|c|}{ Variable } \\
\hline & \multicolumn{2}{|c|}{ Quantitative } & \multicolumn{2}{|c|}{ Qualitative } \\
\hline & Axis 1 & Axis 2 & Axis 1 & Axis 2 \\
\hline \multicolumn{5}{|l|}{ Species' contribution (\%) } \\
\hline Apareiodon ibitiensis & 1.21 & 0.00 & 0.92 & 2.73 \\
\hline Apareiodon piracicabae & 0.24 & 8.02 & 0.28 & 15.29 \\
\hline Astyanax altiparanae & 2.04 & 1.68 & 1.28 & 8.77 \\
\hline Astyanax cf. fasciatus & 0.21 & 0.18 & 9.38 & 4.36 \\
\hline Astyanax eigenmanniorum & 3.21 & 13.80 & 2.46 & 0.02 \\
\hline Bryconamericus sp.1 & 6.32 & 7.31 & 0.18 & 9.80 \\
\hline Bryconamericus sp.2 & 0.03 & 12.18 & 2.60 & 2.32 \\
\hline Cetopsorhamdia cf. iheringi & 10.20 & 0.25 & 9.84 & 0.11 \\
\hline Characidium fasciatum & 0.00 & 3.51 & 0.12 & 3.69 \\
\hline Characidium gomesi & 0.53 & 0.56 & 0.00 & 1.46 \\
\hline Cichlasoma paranaense & 0.04 & 2.81 & 3.14 & 2.38 \\
\hline Cyphocarax modestus & 0.45 & 0.01 & 0.16 & 0.98 \\
\hline Gymnotus carapo & 0.56 & 1.32 & 2.59 & 0.09 \\
\hline Hisonotus sp. & 7.36 & 0.82 & 5.07 & 0.01 \\
\hline Hoplias aff. malabaricus & 15.88 & 0.04 & 21.04 & 0.05 \\
\hline Hyphessobrycon sp. & 1.21 & 1.93 & 3.42 & 0.11 \\
\hline Hypostomus ancistroides & 2.16 & 3.23 & 0.00 & 0.00 \\
\hline Hypostomus margaritifer & 6.44 & 6.46 & 3.38 & 11.00 \\
\hline Hypostomus nigricans & 0.29 & 8.77 & 0.57 & 4.61 \\
\hline Hypostomus regani & 0.21 & 0.00 & 0.01 & 2.90 \\
\hline Hypostomus sp. & 15.17 & 2.60 & 10.35 & 0.10 \\
\hline Imparfinis sp. & 0.21 & 0.11 & 0.23 & 0.99 \\
\hline Laetacara $\mathrm{sp}$. & 0.60 & 0.24 & 0.00 & 1.46 \\
\hline Leporinus microphthalmus & 1.53 & 2.55 & 2.10 & 0.31 \\
\hline Neoplecostomus paranensis & 0.00 & 0.13 & 0.64 & 0.20 \\
\hline Parodon nasus & 0.54 & 4.56 & 2.32 & 3.47 \\
\hline Phenacorhamdia sp. & 0.21 & 0.11 & 0.23 & 0.99 \\
\hline Piabina argentea & 7.49 & 0.05 & 10.83 & 7.58 \\
\hline Pimelodus sp. & 0.00 & 0.89 & 2.88 & 7.57 \\
\hline Planaltina myersi & 3.48 & 13.76 & 2.09 & 0.42 \\
\hline Poecilia reticulata & 3.46 & 0.09 & 0.27 & 0.06 \\
\hline Rhamdia quelen & 0.21 & 0.11 & 0.23 & 0.99 \\
\hline Synbranchus marmoratus & 0.01 & 0.83 & 0.23 & 0.04 \\
\hline Tilapia rendalli & 5.80 & 0.71 & 0.92 & 0.19 \\
\hline Trichomycterus sp. & 2.56 & 0.31 & 0.06 & 4.79 \\
\hline \multicolumn{5}{|l|}{ Variables' contribution (\%) } \\
\hline Water temperature & 2.76 & 34.66 & - & - \\
\hline Dissolved oxygen & 9.77 & 14.26 & - & - \\
\hline $\mathrm{pH}$ & 0.96 & 28.5 & - & - \\
\hline Conductivity & 10.85 & 2.58 & - & - \\
\hline Turbidity & 12.19 & 15.52 & - & - \\
\hline Luminosity & 9.24 & 1.77 & - & - \\
\hline Water velocity & 26.05 & 0.71 & - & - \\
\hline Channel width & 28.14 & 1.97 & - & - \\
\hline Sand & - & - & 0.00 & 0.00 \\
\hline Gravel & - & - & 39.02 & 21.06 \\
\hline Rock & - & - & 18.99 & 1.58 \\
\hline Mud & - & - & 28.23 & 2.77 \\
\hline Anthropogenic perturbations & - & - & 13.75 & 74.57 \\
\hline \multicolumn{5}{|l|}{ Statistics } \\
\hline Eigenvalues & 1.4983 & 0.9766 & 1.5009 & 9.0450 \\
\hline Correlation (r) & 0.86 & 0.9 & 0.74 & 0.75 \\
\hline Explained inertia (\%) & 42.46 & 27.68 & 51.52 & 31.05 \\
\hline Total explained inertia (\%) & \multicolumn{2}{|c|}{70.14} & \multicolumn{2}{|c|}{82.57} \\
\hline $\begin{array}{l}\text { Monte Carlo test (1 } 000 \\
\text { permutations) }\end{array}$ & \multicolumn{2}{|c|}{$\mathrm{p}=0.000$} & \multicolumn{2}{|c|}{$\mathrm{p}=0.084$} \\
\hline
\end{tabular}

Hypostomus (Casatti, 2002; Fialho \& Tejerina-Garro, 2004; Hahn et al., 1998; Melo et al., 2005; Santos et al., 2004). Also, these catfish display body shapes and morphological adaptations of the pectoral fins that aid them in maintaining position in high velocity areas of streams (Casatti, 2002; Melo et al., 2005). In addition, the catfish $C$. cf. iheringi is reported to be invertivorous (Casatti \& Castro, 1998; Froese \& Pauly, 2008; Oliveira et al., 1997), feeding predominantly on aquatic insect larvae such as those of the family Leptophlebiidae, Hydropsychidae, Hydroptilidae (Casatti \& Castro, 1998), which are present in streams of the Upper Paraná River (Oliveira et al., 1997). In the case of the characin P. argentea, its fusiform body, terminal mouth position (Fialho \& TejerinaGarro, 2004), small size and opportunistic feeding behavior facilitate its exploitation of different lotic habitats along the margins of water courses (Ferreira \& Casatti, 2006b; Ferreira et al., 2002; Gomiero \& Braga, 2005).

In our study, the characin $H$. aff. malabaricus and the cichlid $T$. rendalli are associated with sites having narrow channels and low water velocities. Such habitats favor $H$. aff. malabaricus, a piscivorous species (Resende, 2000; Santos et al., 2004) that ambushes prey (Fialho \& Tejerina-Garro, 2004) or T. rendalli, which consumes phytoplankton and zooplankton (Dias et al., 2005; Lazzaro, 1991). In addition, low water velocities favor reproduction of $H$. aff. Malabaricus, which prefers lentic and muddy waters for spawning (AraújoLima \& Bittencourt, 2001; Nakatani et al., 2001) as well as $T$. rendalli (Fialho \& Tejerina-Garro, 2004; Oliveira \& Bennemann, 2005).

The dry and wet seasons (IBGE, 2005) accentuate physicochemical water characteristics, particularly $\mathrm{pH}$ and water temperature (Esteves, 1988; Gordon et al., 1995; Melo et al., 2003). During dry seasons the fish assemblages represented by the characins $A$. eigenmanniorum, Bryconamericus sp.1, Bryconamericus sp.2, P. myersi, A. piracicabae and the catfish $H$. nigricans are associated with sites having acidic water (average $\mathrm{pH}=6.12$ ) and relatively low water temperatures (average $=22.31^{\circ} \mathrm{C}$ ), whereas in wet seasons the catfish $H$. margaritifer and the characin P. nasus are linked with sites having relatively basic water (average $=$ 8.08) and higher water temperatures (average $=24.37^{\circ} \mathrm{C}$ ).

The influence of $\mathrm{pH}$ on fish assemblage structure was also observed by Abes \& Agostinho (2001), Braga \& Andrade (2005), Fialho et al. (2008) and Penczak et al. (1994), in streams of the Upper Paraná River. In our study the $\mathrm{pH}$ influence seemed to be related mostly to regional soil characteristics and land uses. The Ouvidor River basin drains Cerrado regions characterized by naturally acidic soils (Ratter et al., 1997), where the main economic activity is farming and cattle ranching (Nepstad et al., 1997). These activities require the addition of calcium before the rainy season to reduce soil acidity sufficiently to enable profitable agricultural activities (Ratter et al., 1997). This fertilization introduces $\mathrm{Mg}$ and $\mathrm{Ca}$ ions into the water courses during the wet seasons and results in more basic $\mathrm{pH}$ of the water (Carvalho et al., 2000). However, it is not possible to determine from our study weather the preference of the fish species for basic or acidic water is related to the influence of $\mathrm{pH}$ on reproduction (Dei Tos et al., 2002) or growth and development (Esteves, 1988; Ferreira et al., 2001).

Esteves (1988) stated that one ecological consequences 

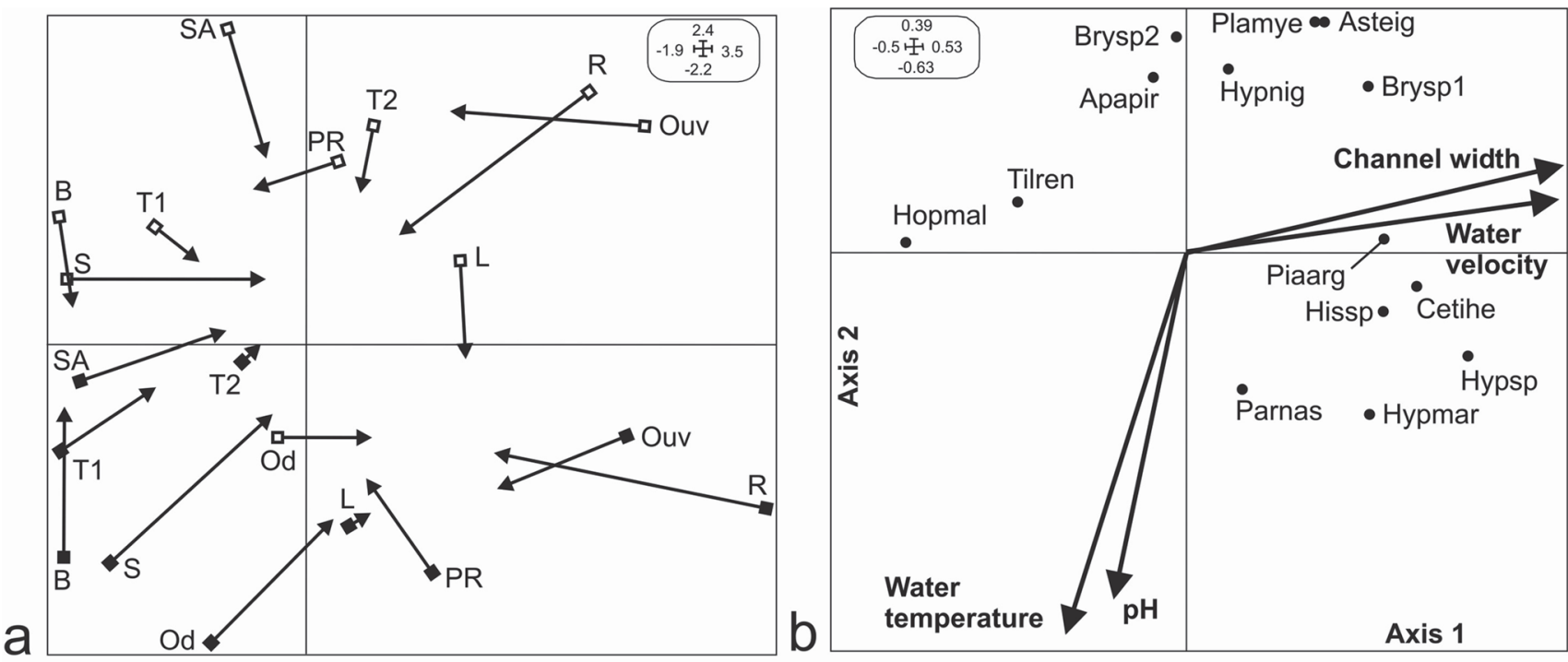

Fig. 2. Ordination of the co-structure between (a) fish assemblages (arrows) and stream sites (squares) and (b) fish species and environmental variables resulting from the co-inertia analysis. Only species that most contributes to each axis are displayed. Black and white squares represent stream sites sampled in the wet and dry season, respectively. Codes correspond to names listed in Tables 1 and 2. Small boxes indicate the graphic scale.

Table 5. Averages values of the quantitative variables by stream and season. DS = dry season; WS = wet season.

\begin{tabular}{|c|c|c|c|c|c|c|c|c|c|c|c|c|c|c|c|c|}
\hline \multirow[t]{2}{*}{ Stream } & \multicolumn{2}{|c|}{$\begin{array}{c}\text { Water } \\
\text { temperature }\left({ }^{\circ} \mathrm{C}\right)\end{array}$} & \multicolumn{2}{|c|}{$\begin{array}{c}\mathrm{DO} \\
(\mathrm{mg} / \mathrm{L})\end{array}$} & \multicolumn{2}{|c|}{$\mathrm{pH}$} & \multicolumn{2}{|c|}{$\begin{array}{l}\text { Conductivity } \\
(\mu \mathrm{S} / \mathrm{cm})\end{array}$} & \multicolumn{2}{|c|}{$\begin{array}{c}\text { Turbidity } \\
\text { (UTN) }\end{array}$} & \multicolumn{2}{|c|}{$\begin{array}{c}\text { Luminosity } \\
\text { (lux) }\end{array}$} & \multicolumn{2}{|c|}{$\begin{array}{c}\text { Water } \\
\text { velocity }(\mathrm{cm} / \mathrm{s})\end{array}$} & \multicolumn{2}{|c|}{$\begin{array}{l}\text { Channel } \\
\text { width (m) }\end{array}$} \\
\hline & DS & WS & $\mathrm{DS}$ & WS & DS & WS & DS & WS & DS & WS & DS & WS & DS & WS & DS & WS \\
\hline Taquara II & 20.47 & 22.93 & 7.40 & 7.78 & 6.08 & 7.72 & 40.77 & 50.67 & 7.06 & 20.33 & 8.44 & 8.44 & 34.69 & 6.15 & 3.36 & 3.18 \\
\hline Taquara I & 24.13 & 26.00 & 6.25 & 5.76 & 5.68 & 8.25 & 31.27 & 24.98 & 12.48 & 18.33 & 12.50 & 12.50 & 36.46 & 22.30 & 1.97 & 2.36 \\
\hline Buraco & 23.50 & 24.20 & 6.50 & 8.80 & 6.19 & 8.62 & 91.70 & 115.10 & 3.75 & 50.30 & 10.94 & 10.94 & 24.58 & 11.71 & 1.07 & 1.19 \\
\hline Santo Antônio & 19.10 & 23.07 & 6.50 & 7.52 & 6.39 & 8.66 & 110.77 & 142.17 & 10.69 & 17.45 & 10.50 & 10.50 & 32.02 & 8.11 & 4.67 & 4.51 \\
\hline Lagoa & 22.37 & 24.63 & 7.90 & 8.42 & 6.39 & 8.14 & 20.43 & 24.83 & 5.50 & 48.09 & 9.83 & 9.83 & 55.97 & 27.88 & 3.92 & 3.96 \\
\hline Ouvidor & 20.30 & 23.25 & 8.25 & 8.06 & 6.54 & 7.65 & 65.83 & 77.20 & 11.37 & 300.21 & 9.56 & 9.56 & 64.85 & 44.87 & 8.90 & 8.88 \\
\hline Posse dos Rodrigues & 21.33 & 23.07 & 7.45 & 9.64 & 5.98 & 8.36 & 43.17 & 40.93 & 6.92 & 126.69 & 9.39 & 9.39 & 34.11 & 26.75 & 3.47 & 3.70 \\
\hline Riacho & 20.37 & 22.10 & 7.50 & 8.08 & 5.93 & 7.36 & 29.90 & 29.35 & 23.30 & 504.10 & 9.17 & 9.17 & 69.79 & 68.17 & 5.78 & 5.83 \\
\hline Sapê & 24.93 & 25.63 & 6.55 & 7.65 & 5.92 & 8.24 & 68.30 & 70.40 & 20.26 & 100.33 & 13.06 & 13.06 & 5.85 & 12.10 & 4.25 & 3.94 \\
\hline Olhos d'água & 26.57 & 28.85 & 7.95 & 8.13 & 6.08 & 7.79 & 34.70 & 45.65 & 32.47 & 36.00 & 12.06 & 12.06 & 47.18 & 44.87 & 2.50 & 2.34 \\
\hline
\end{tabular}

of the specific heat of water is relatively high thermal stability of aquatic ecosystems, and Wetzel (1993) suggested that thermal radiation into and from water reservoirs is predominantly a superficial phenomenon that is, restricted to the top centimeters of the water column. In this way, water courses with less water volume (e.g., streams) tend to gain and lose heat more rapidly than ones with more volume (e.g., river). This seemed to be the situation in our study when comparing the Ouvidor River with the Buraco and Sapê streams during the wet season, and all stream sites in both seasons. However, streams with riparian vegetation cover have lower water temperatures than uncovered ones (Ferreira \& Casatti, 2006b), which seems to be the case of the Olhos d'água and Posse dos Rodrigues streams, where H. margaritifer and P. nasus are predominant. Generally, the influence of water temperature on fish is related to their metabolism (Silva \& AraújoLima, 2003), which was not measured in our study. In sites lacking vegetation cover, the availability of light in the water column increases (Tejerina-Garro \& Mérona, 2001). The increased light and additional nutrients from wet season run off favored increased periphyton production, which is consumed by H. margaritifer (Casatti, 2002; Hahn et al., 1998; Melo et al., 2005; Santos et al., 2004;) and P. nasus (Fialho \& Tejerina-Garro, 2004).

In conclusion, we found that fish assemblages of Ouvidor basin streams sites were structured by water velocity, channel width, $\mathrm{pH}$ and water temperature. Although we did not detect direct effects of anthropogenic perturbations on fish assemblages in this study, it does not mean that they were absent. Our results aids predictions of the responses of Ouvidor fish assemblages to environmental modifications, including those that take place at a large temporal and spatial scale such as air temperature.

Additional studies are necessary to verify if the fish-habitat relationships observed for our Ouvidor stream sites prevail at the larger spatial scale of the Paranaíba River basin in 
Goiás, where streams were modified without prior knowledge of the structure and composition of the aquatic assemblages, including fish.

\section{Acknowledgments}

The authors thank the team of the Centro de Biologia Aquática, specially Tatiana Lima de Melo and Waldeir Francisco de Menezes, for field help; the Aroeira Foundation and the Neotropica Tecnologia Ambienttal Ltda. for logistical and financial support; R. M. Hughes of the Oregon University for English editing; and two anonymous referees for critical reviews. The first author was supported by a CAPES/Brazil's scholarship.

\section{Literature Cited}

Abes, S. S. \& A. A. Agostinho. 2001. Spatial patterns in fish distributions and structure of the ichthyocenosis in the Água Nanci stream, upper Paraná River basin, Brazil. Hydrobiologia, 445: 217-227.

Agostinho, A. A., H. F. Júlio-Jr. \& J. R. Borghetti. 1992. Considerações sobre os impactos dos represamentos na ictiofauna e medidas para sua atenuação, um estudo de caso: reservatório de Itaipú. Revista UNIMAR, 14(Suplemento): 089-107.

Angermeier, P. L. \& J. R. Karr.1994. Biological integrity versus biological diversity as policy directives: protecting biotic resources. Bioscience, 44: 690-697.

Araújo-Lima, C. A. R. M. \& M. M. Bittencourt. 2001. A reprodução e o início da vida de Hoplias malabaricus (Erythrinidae; Characiformes) na Amazônia Central. Acta Amazônica, 31(4): 693-697.

Bennemann, S. T., A. M. Gealh, M. L. Orsi \& L. M. Souza. 2005. Ocorrência e ecologia trófica de quatro espécies de Astyanax (Characidae) em diferentes rios da bacia do rio Tibagi, Paraná, Brasil. Iheringia, Série Zoologia, 95(3): 247-254.

Bini, L. M. 2004. Análises Multivariadas e Limnologia: Exploração, Síntese e Inferência de um Mundo Aquático Complexo. Pp73107. In: Bicudo C. E. M. \& D. C. Bicudo. Amostragem em Limnologia. São Carlos, SP, Editora RiMa, 371p.

Braga, F. M. S. 2004. Habitat, distribuição e aspectos adaptativos de peixes da microbacia do ribeirão Grande, Estado de São Paulo, Brasil. Acta Scientiarum Biological Sciences, 26(1): 31-36.

Braga, F. M. S. \& P. M. Andrade. 2005. Distribuição de peixes na microbacia do Ribeirão Grande, Serra da Mantiqueira Oriental, São Paulo, Brasil. Iheringia. Série Zoologia, 95(2): 121-126.

Carvalho, A. R., F. H. M. Schlitter \& V. L. Tornisielo. 2000. Relações da atividade agropecuária com parâmetros físico-químicos da água. Química Nova, 23(5): 618-622.

Casatti, L. 2002. Alimentação dos peixes em um riacho do Parque Estadual Morro do Diabo, bacia do alto rio Paraná, Sudeste do Brasil. Biota Neotropica, 2(2): 1-14.

Casatti, L.\& R. M. C. Castro. 1998. A fish community of the São Francisco river headwaters riffles, southeastern Brazil. Ichthyological Explorations Freshwaters, 9(3): 229-242.

Cunico, A. M., A. A. Agostinho \& J. D. Latini. 2006. Influência da urbanização sobre as assembléias de peixes em três córregos de Maringá, Paraná. Revista Brasileira de Zoologia, 23(4): 1101-1110.

Dei Tos, C., G. Barbieri G, A. A. Agostinho, L. C. Gomes \& H. I. Suzuki. 2002. Ecology of Pimelodus maculatus (Siluriformes) in the Corumbá Reservoir, Brazil. Cybium, 26(4): 275-282.
Dias, R. M., D. Bailly, R. R. Antonio, H. I. Suzuki \& A. A. Agostinho. 2005. Colonization of the Corumbá Reservoir (Corumbá River, Paraná River Basin, Goiás State, Brazil) by the "lambari" Astyanax altiparanae (Tetragonopterinae, Characidae). Brazilian Archives of Biology and Technology, 48: 467-476.

Dolédec, S. \& D. Chessel. 1991. Recent developments in linear ordination methods for environmental sciences. Advances in Ecology, 1: 133-154.

Dolédec, S. \& D. Chessel. 1994. Co-inertia analysis: an alternative method for studying species-environment relationships. Freshwater Biology, 31: 277-294.

Esteves, F. A.1988. Fundamentos de Limnologia. Interciência, Rio de Janeiro

Esteves, K. E. \& J. Lobón-Cerviá. 2001. Fish composition and trophic structure of a clear water Atlantic rainforest stream in Southeastern Brazil. Environmental Biology of Fishes, 62: 429-440.

Ferreira, A., A. P. O. Nuñer \& J. R. Esquivel. 2001. Influência do pH sobre ovos e larvas de jundiá, Rhamdia quelen (Osteichthyes, Siluriformes). Acta Scientiarum Biological Sciences, 23(2): 477-481.

Ferreira, A., N. S. Hahn \& R. L. Delariva. 2002. Ecologia alimentar de Piabina argentea (Teleostei, Tetragonopterinae) nas fases pré e pós-represamento do rio Corumbá, GO. Acta Limnologica Brasiliensia, 14(1): 43-52.

Ferreira, C. P. \& L. Casatti. 2006a. Influência da estrutura do hábitat sobre a ictiofauna de um riacho em um micro-bacia de pastagem São Paulo, Brasil. Revista Brasileira de Zoologia, 23(3): 642-651.

Ferreira, C. P. \& L. Casatti. 2006b. Integridade biótica de um córrego na bacia do Alto Rio Paraná avaliada por meio da comunidade de peixes. Biota Neotropica, 6(3): 1-25.

Fialho. A. P. \& F. L. Tejerina-Garro.2004. Peixes da bacia do rio Meia Ponte, GO. Série Didática 12, Goiânia, Editora da UCG, 105p.

Fialho, A. P., L. G. Oliveira, F. L. Tejerina-Garro \& B. Mérona. 2008. Fish-habitat relationship in a tropical river under anthropogenic influences. Hydrobiologia, 598: 315-324.

Froese, R. \& D. Pauly (Ed). 2008. Cetopsorhamdia iheringi In: FishBase. World Wide Web eletronic publication. Available via DIALOG.http://www.fishbase.org// Sum mary/ species Summary.php? ID $=47828 \&$ genusname $=$ Cetopsorhamdia\&speciesname=iheringi. Acessed 19 May 2008.

Gomiero, L. M. \& F. M. S. Braga. 2005. Length structure of fishes from a protected area in the State of São Paulo, Southeastern Brazil. Acta Scientarium Biological Sciences, 27(4): 339-346.

Gorman, O. T \& J. R. Karr. 1978. Habitat structure and stream fish communities. Ecology, 59(3): 507-515.

Gordon, N. D., T. A. McMahon \& B. L. Finlayson. 1995. Stream hydrology: an introduction for ecologists. England, John Wiley \& Sons, 576p.

Hahn, N. S., A. A. Agostinho, L. C. Gomes \& L. M. Bini. 1998. Estrutura trófica da ictiofauna do reservatório de Itaipu (ParanáBrasil) nos primeiros anos de sua formação. Interciência, 23(5): 299-305.

IBGE. 2005. Atlas nacional do Brasil digital. In: Instituto Brasileiro de Geografia e Estatística. Available via DIALOG. http:// mapas.ibge.gov.br/clima/viewer.htm. Acessed 22 Mai 2008.

Jackson, D. A., P. R. Peres-Neto \& J. D. Olden. 2001. What controls who is where in freshwater fish communities - the roles of biotic, abiotic, and spatial factors. Canadian Journal of Fisheries and Aquatic Sciences, 58: 157-170.

Lazzaro, X. 1991. Feeding convergence in South American and African zooplanktivorous cichlids Geophagus brasiliensis and Tilapia rendalli. Environmental Biology of Fishes, 31(3): 283-293.

Lomnicky, G. A., T. R. Whittierb, R. M. Hughes \& D. V. Peckc. 
2007. Distribution of nonnative aquatic vertebrates in Western U.S. streams and rivers. North American Journal of Fisheries Management, 27(4): 1082-1093.

Lowe-McConnell, R. H. 1999. Estudos ecológicos de comunidades de peixes tropicais. São Paulo, EDUSP, 534p.

Matthews, W. J. 1998. Patterns in freshwater fish ecology. New York, Chapman \& Hall, 756p.

Mazzoni, R., N. Fenerich-Verani \& E. P. Caramaschi. 2000. A pesca elétrica como técnica de amostragem de populações e comunidades de peixes em rios costeiros do sudeste do Brasil. Revista Brasileira Biologia, 60(2): 205-216.

McCune, B. \& J. B. Grace. 2002. Analysis of ecological communities. Oregon, mjm, 300p.

Melo, C. E., F. A. Machado \& V. P. Silva. 2003. Diversidade de peixes em um córrego de Cerrado no Brasil Central. Brazilian Journal of Ecology, 1-2: 17-23.

Melo, C.E., J. D. Lima, T. L. Melo \& V. P. Silva. 2005. Peixes do Rio das Mortes: Identificação e ecologia das espécies mais comuns. Cáceres, UNEMAT, 145p.

Mendonça, F. P., W. E. Magnusson \& J. Zuanon. 2005. Relationships between habitat characteristics and fish assemblages in small streams of Central Amazonia. Copeia, 4: 751-764.

Mérigoux, S., D. Ponton \& B. Mérona. 1998. Fish richness and specieshabitat relationships in two coastal streams of French Guiana, South America. Environmental Biology of Fishes, 51: 25-39.

Mérona, B., R. Vigouroux \& F. L. Tejerina-Garro. 2005. Alteration of fish diversity downstream from Petit-Saut Dam in French Guiana: implication of ecological strategies of fish species. Hydrobiologia, 551: 33-47.

Nakatani, K., A. A. Agostinho, G. Baumgartner, A. Bialetzki, P. V. Sanches, M. C. Makrakis \& C. S. Pavanelli. 2001. Ovos e larvas de peixes de água doce: desenvolvimento e manual de identificação. Maringá, EDUEM, 378p.

Nepstad, D. C., C. A. Klink, C. Uhl, I. C. Vieira, P. Lefebvre, M. Pedlowski, E. Matricardi, G. Negreiros, I. F. Brown, E. Amaral, A. Homma \& R. Walker. 1997. Land-use in Amazonia and the cerrado of Brazil. Ciência e Cultura, 49(1-2): 73-86.

Oliveira, L. G., P. C. Bispo \& N. C. Sá. 1997. Ecologia de comunidades de insetos bentônicos (Ephemeroptera, Plecoptera e Trichoptera), em córregos do parque ecológico de Goiânia, Goiás, Brasil. Revista Brasileira de Zoologia, 14(4): 867-876.

Oliveira, J. C. \& A. K. G. Lacerda. 2004. Alterações na composição e distribuição longitudinal da ictiofauna na área de influência do reservatório de Chapéu d'Uvas, bacia do rio Paraíba do Sul (MG), pouco depois da sua implantação. Revista Brasileira de Zoociências, 6(1): 45-60.

Oliveira, D.C. \& S. T. Bennemann. 2005. Ictiofauna, recursos alimentares e relações com as interferências antrópicas em um riacho urbano no sul do Brasil. Biota Neotropica, 5(1): 95-107.

Penczak, T, A. A. Agostinho \& E. K. Okada. 1994. Fish diversity and community structure in two tributaries of the Paraná River, Paraná State, Brazil. Hydrobiologia, 294: 243-251.

Poff, N. L. 1997. Landscape filters and species traits: towards mechanistic understanding and prediction in stream ecology. Journal of the North American Benthological Society, 16: 391-409.

Poff, N. L., J. D. Allan, M. B. Bain, J. R. Karr, K. L. Prestegaard, B. D. Richter, R. E. Sparks \& J. C. Stromberg. 1997. The natural flow regime: A paradigm for river conservation and restoration. BioScience, 47(11): 769-784.

Ratter, J. A., J. F. Ribeiro \& S. Bridgewater. 1997. The Brazilian Cerrado: vegetation and threats to its biodiversity. Annals of Botany, 80: 223-230.
Resende, E. K. 2000. Trophic structure of fish assemblages in the lower Miranda river, Pantanal, Mato Grosso do Sul State, Brazil. Revista Brasileira de Biologia, 60(3): 389-403.

Ribeiro, J. F. 1998. Cerrado: matas de galeria. Planaltina, EMBRAPA - CPAC, 164p.

Santos, G. M., B. Mérona \& A. A. Juras, 2004. Peixes do baixo Rio Tocantins: 20 anos depois da Usina Hidrelétrica de Tucuruí. Brasília, Eletronorte, 216p.

Severi, W. R. G. Hickson \& T. C. F. Maranhão. 1995. Use of electric fishing for fish fauna survey in Southern Brazil. Revista Brasileira de Biologia, 55(4): 651-660.

Silva, E. C. S. \& C. A. R. M. Araújo-Lima. 2003. Temperatura na evacuação gástrica da piranha caju (Pygocentrus nattereri) em condições experimentais Acta Amazônica, 33(1): 145-156.

Tejerina-Garro, F. L. 2008. Biodiversidade e impactos ambientais no estado de Goiás: o meio aquático. Pp15-48. In: Rocha C., F. L. Tejerina-Garro \& J. P. Pietrafesa (Orgs.). Cerrado, sociedade e ambiente: desenvolvimento sustentável em Goiás. Goiânia, GO, Editora da Universidade Católica de Goiás, 303p.

Tejerina-Garro, F. L. \& B. Mérona. 2001. Spatial variability of biotic and abiotic factors of the aquatic habitat in French Guiana. Regulated Rivers: Research \& Management, 17: 157-169.

Tejerina-Garro, F. L., M. Maldonado, C. Ibáñez, D. Pont, N. Roset \& T. Oberdoff. 2005. Effects of natural and anthropogenic environmental changes on riverine fish assemblages: a framework for ecological assessment of rivers. Brazilian Archives of Biology and Technology, 48(1): 91-108.

Thioulouse, J., D. Chessel, S. Dolédec, J. M. Oliver, F. Goreaud \& R. Pelessier. 2001. Ecological data analysis: exploratory and Euclidean methods in Environmental sciences. Version 2001 CCNRS 1995-2001.

Thomaz, S. M., L. M. Bini \& S. M. Alberti. 1997. Limnologia do reservatório de Segredo: padrões de variação espacial e temporal. Pp 20-37. In: A. A. Agostinho \& L. C. Gomes (eds.) Reservatório de Segredo: bases ecológicas para o manejo. Maringá, EDUEM, 387p.

Tonn, W. M. 1990. Climate change and fish communities: a conceptual framework. Transactions of the American Fisheries Society, 119: 337-352.

Welcomme, R. L. 1979. Fisheries ecology of floodplain rivers. London, Longman Group Limited, 317p.

Wetzel, R. G. 1993. Limnologia. Lisboa, Ed. Fundação Calouste Gulbenkian, 919p.

Zar, J. H. 1998. Biostatistical Analysis (4th ed.). New Jersey, Prentice-Hall Inc., Englewood Cliffs.

Accepted February 2009

Published March 31, 2009 